\title{
Odonata Diversity at University of Southern Mindanao, Kabacan, Cotabato
}

\author{
CHERIE CANO-MANGAOANG \\ ORCID No. 0000-0002-9937-252X \\ chericano1201@gmail.com \\ Department of Biological Sciences, \\ University of Southern Mindanao, \\ Kabacan, Cotabato, Philippines \\ ALMA B. MOHAGAN \\ ORCID No. 0000-0002-8303-5131 \\ almohagan@gmail.com \\ Department of Biological Sciences, \\ Central Mindanao University, Musuan, \\ Maramag, Bukidnon, Philippines
}

\begin{abstract}
Odonata are good biocontrol agents of agricultural pests and vector mosquitoes and even an indicator of environmental changes and health status of ecosystem. However, there are limited studies that have been conducted especially on lowland ecosystems. The study was conducted using time constraint with 4 exposure hours and opportunistic sampling protocols. Result of the study revealed 13 species of odonata belonging to three families, 2 of which are Zygopterans and only one family belonging to Anisoptera with 11 species. Libellulidae dominates the recorded species. 8 species are found in USMARC and 6 species in housing. One Philippine endemic was documented - Rhinocypha colorata. Diversity is low in the two sampling sites and high disturbance is found in housing (63\%). Similarity index showed that $92 \%$ are disconcordant species. Low species diversity and low endemism of odonata is an indicator that the area is already disturbed as measured by the high number of common/oriental species
\end{abstract}


and existence of environmental and anthropogenic activities. Thus, a conservation strategy for this important species will be implemented.

Keywords: odonata, USM, disturbance, oriental species

\section{INTRODUCTION}

The order Odonata includes both the dragonflies and damselflies separated into three suborders: Anisoptera, Zygoptera and Anizygoptera (Williams and Feltmate 1992). They can be seen often flying back and forth or darting inconsistently from early morning until late evenings. Researches in different parts of the globe have revealed that insects like odonata are good indicators of health status of certain ecosystem (Subramanian et al. 2008). Odonata are also important as good indicators of environmental changes as they are sensitive to changes in the habitats, atmospheric temperature and weather conditions (Tiple et al. 2012). The authors further mentioned that this group of insects is also a good biocontrol agents. Odonata is one of the groups of insects which experiences numerous shifts in distribution and abundance and consequently extinction risk and biodiversity loss (Thomas et al. 2004). The deterioration of freshwater habitats across the globe prompted an increased concern on Odonata (Nelson et al. 2011).

Given the facts on the importance of Odonata, only a few studies have been conducted here in the Philippines due to only a few researchers are interested in exploring these species (Cayasan et al. 2013). In the study of Quisil et al. (2013) on Odonata of Lanuza and San Agustin, Surigao del Sur has found two species which are new Mindanao record. Villanueva and Mohagan (2010) found out three new species of damselflies in Mt. Hamiguitan Wildlife Sanctuary. Villanueva (2011 a,b) reported new records from his Odonata surveys in some parts of the Philippines like Diomabok Lake in Davao Oriental, Catanduanes Island, and Siargao and Bucas Grande islands. He emphasized the need in exploring various areas in the archipelago since several parts of the archipelago's main islands like Mindanao are almost unexplored. Mindanao, as one of the three large island groups, has a rich diversity of fauna and is considered to possess a high level of biodiversity due to high mountain ranges (Amoroso 2007). North Cotabato specifically municipality of Kabacan in Mindanao, Philippines is one of the places with poor odonatological record. Thus, this study was conducted to document the species of Odonata found in the area of the University of Southern Mindanao, Kabacan, Cotabato. 


\section{OBJECTIVES OF THE STUDY}

This study aimed to document the species of Odonata found in the area of the University of Southern Mindanao, Kabacan, Cotabato.

\section{MATERIALS AND METHODS}

\section{Site Selection}

The University of Southern Mindanao is at N 701'60 E $124^{0} 52^{\prime}$ 60. It is located north in the heart of Kabacan, Cotabato more or less 600 meters from the main thorough fare. Two stations were established during the collection: one at the USM Agricultural Research Center (USMARC) - N $7^{0} 06.600^{\prime} \mathrm{E} 124^{\circ}$ $50.551^{\prime}$ and the one at USM Housing ( $\mathrm{N} 7^{0} 07.392 \mathrm{E} 124^{\circ} 49.589$ ).

USMARC is surrounded by agricultural crops. Most of the area is planted with rice, a portion of it is planted with banana, corn and fruit bearing trees such as lanzones, rambutan and durian, mangosteen (Garcinia mangostana) and Citrus maxima (Plate 1). Meanwhile, USM housing is on the western side of the University of Southern Mindanao. The area is also surrounded by agricultural crops such as corn, oil palm tree and few area planted with rice. Vacant lots are also planted with lemon grass (Plate 2). Furthermore, housing is inhabited by people. Both sampling areas are exposed to sunlight (open).

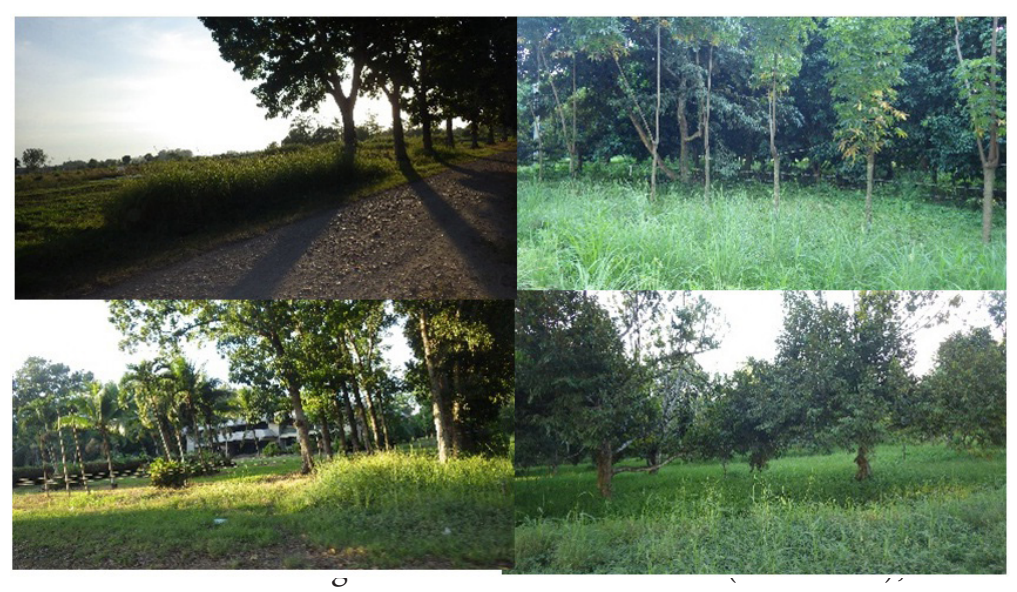

USM, Kabacan, Cotabato 2014. 


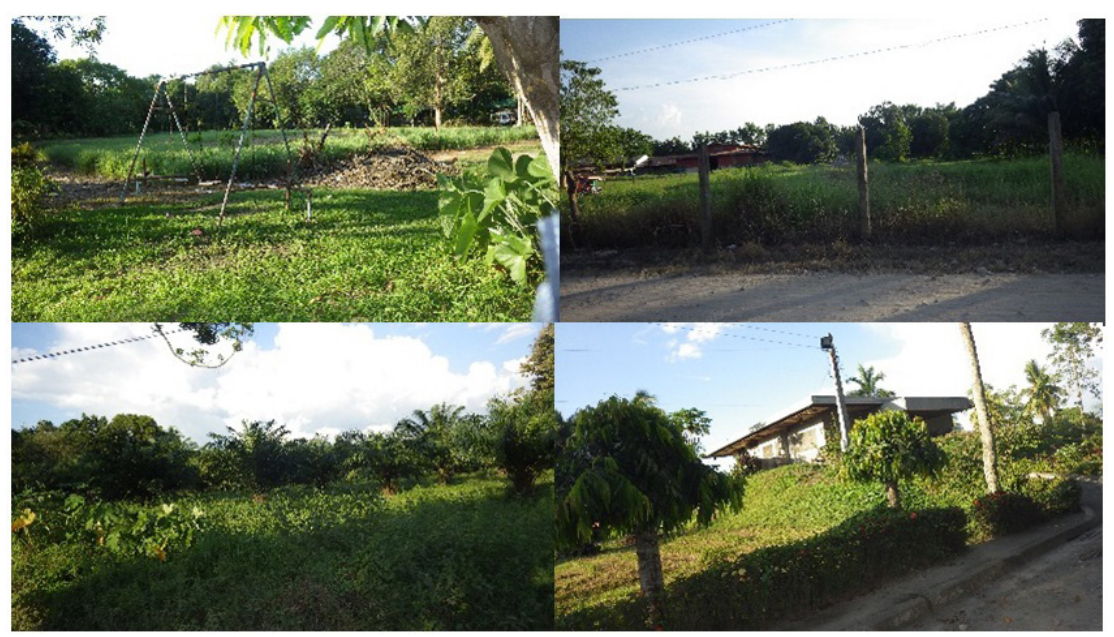

Plate 2. Faculty Housing, University of

Southern Mindanao, Kabacan, Cotabato 2014.

\section{Collection}

Opportunistic sampling and 4-hour time constraint techniques at $8 \mathrm{am}-12 \mathrm{nn}$ exposure for two-month in 2014. Odonata was collected using a catching net.

\section{Preservation}

The three specimens of Odonata per species were soaked in ethyl acetate and placed in the triangular wax paper with moth balls to preserve them.

\section{Classification, Identification, and Description}

Classification and initial identification of Odonata were done using books, journals, and photographs of identified specimens.

\section{Diversity Index and Cluster Analysis}

Diversity index and cluster analysis were determined using BIO PRO software version 2.0 following Villanueva and Mohagan, 2010. 


\section{RESULTS AND DISCUSSION}

Thirteen species of Odonata were recorded collectively from USMARC and USM Housing during the sampling periods. The diversity index showed differences between the two sampling areas. Two families namely: Protoneuridae and Chlorocyphidae were recorded under Zygoptera and only one family was recorded under Anisoptera- Libellulidae (Table 1). In the recorded species, 11 were Anisoptera and only 2 are Zygopterans. Libellulidae was found to dominate the species documented. The recorded species is dominated by Pantala flavescens in Housing and Diplacodes triviales in USMARC. Furthermore, eight species are found in USMARC and six species in housing.

The result further reveals that most of the collected species are oriental, and only one is endemic to the Philippines - Rhinocypha colorata.

Table 1. Identified Species of Odonata at USM, Kabacan, Cotabato 2014

\begin{tabular}{lcc}
\hline \hline Species & Housing & USMARC \\
\hline ZYGOPTERA & & \\
PROTONEURIDAE & & $\mathrm{x}$ \\
Caconeura ramburi & & \\
CHLOROCYPHIDAE & $\mathrm{x}$ \\
Rhinocypha colorata & & \\
ANISOPTERA & & \\
LIBELLULIDAE & $\mathrm{x}$ & $\mathrm{x}$ \\
Brachydiplax chalybea & & $\mathrm{x}$ \\
Brachythemis contaminata & & $\mathrm{x}$ \\
Crocothemis erythraea & & $\mathrm{x}$ \\
Diplacodes triviales & & \\
Lathrecista asiatica asiatica & $\mathrm{x}$ & \\
Macrodiplax sp & & $\mathrm{x}$ \\
Neurothemis terminata & $\mathrm{x}$ & \\
Orthetrum sabina sabina & $\mathrm{x}$ & \\
Pantala flavescene & $\mathrm{x}$ & $\mathrm{x}$ \\
Potomarcha congener & & \\
Raphismia bispina & & \\
\hline \hline
\end{tabular}


The result of the present study reports the diversity of Odonata in agricultural and human inhabited areas. According to Anbalagan et al. (2013) odonates are insectivorous thus an important biocontrol agents of agricultural pests and vector mosquitoes. In the current study, species under Libellulidae dominates and greatest in number. Similar findings were previously reported by various researchers. Bashar et al. (2014) have reported highest species diversity with 22 species in five selected areas of Bangladesh. Saha and Gaikwad (2014) reported that Libellulidae was the most dominant family represented by 20 species in parks and gardens in Pune City, India. Related results were published by Dorji (2014); Bora and Meitie (2014); Adarsh et al. (2014); Tiple et al. (2012); Mapiot et al. (2013); and Cayasan et al. (2013). Libellulidae is highly spread out worldwide and even in local areas because it is the biggest family of dragonfly worldwide. Aside from this, most species under this family usually populate open and sunny environments as well as in disturbed habitat (Cayasan et al. 2013) because thermoregulation is made possible by solar radiation in larger species (Dalzochio et al. 2011) of dragonfly such as in Family Libellulidae. Result of this study conforms to the findings of the above investigators. Moreover, their body size which are larger can be associated to their pattern of distribution (Dalzochio et al. 2011). More species of Anisopterans found in this study might be attributed to the type of ecosystem the sampling area which is exposed to sunlight. According to Arulprakash and Gunathilagaraj (2010) that the presence of shade cover and aquatic vegetation favors Zygopterans than Anisopterans. It was also observed by Remsburg et al. (2008) that dragonfly abundance is lower in sites with high or moderate shade cover. Mapi-ot et al. (2013) mentioned that Libellulidae are very common in lowland areas such as ricefields.

The result of the study also reveals that most of the noted species are predominantly oriental and widespread species. Quisil et al. (2014) oriental dragonflies species can endure disturbance and subsequently survive even the harshest environment. Therefore, they are good indicators of the degraded environment (Cayasan et al. 2013).

In this study, the number of species recorded is higher compared to that in the work of Kandinabe et al. (2005) which recorded only 12 taxa of Odonata in an irrigated rice field of Madurai. Villanueva and Mohagan (2010) documented only 4 species from the agro-ecosystem of Mt. Hamiguitan. Jomoc et al. (2013) recorded 12 and 6 species of Odonata in their sampling sites 4 and 6, respectively, which is almost the same description with the sampling sites of this study. Soniyagandhi and Kumar (2014) recorded 8 species of Odonata in rice ecosystem 
at Pandit Jawaharlal Nehru College of Agriculture and Research Institute, India.

Only one endemic species was documented-Rhinocypha colorata, a Philippine endemic that can tolerate disturbed habitats (Mapi-ot et al. 2013). This species is found in USMARC which is an agricultural. According to Villanueva (2012) it can be observed even in places with human activity and tolerant to streams with agricultural and domestic runoffs.

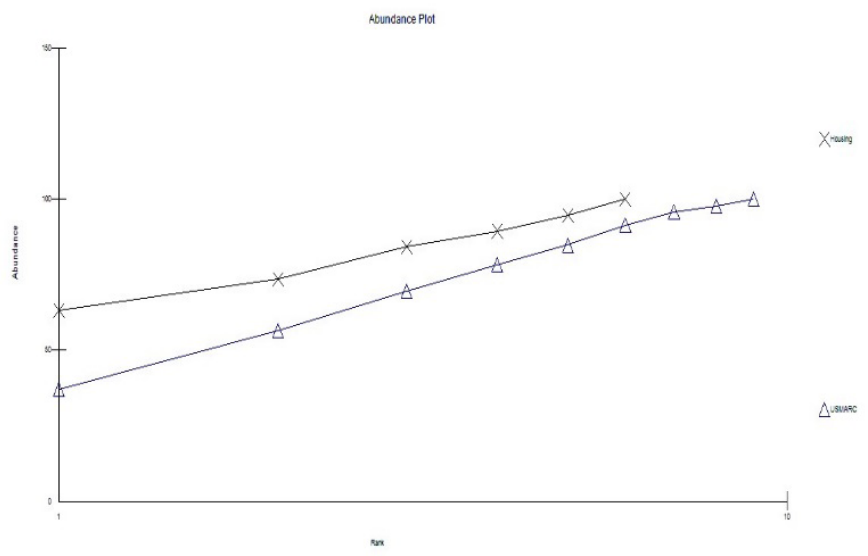

Figure 1. K Plot of Abundance on Odonata Species in USM, Kabacan, Cotabato 2014.

K plot of abundance (Figure 1) reveals that ampleness of sampling was not yet reached, and this implies that additional sampling is needed for possible turnover of the species. Shannon-Weiner index was low in the two sampling areas and a less even distribution is noted (Table 2). The low diversity of species might be attributed also to the limited sampling period (as shown in Figure 1) which decreases the chance of finding isolated and secretive species (Mapi-ot et al. 2013). Villanueva and Mohagan (2010) also reported lowest diversity index in agro-ecosystem in Mt. Hamiguitan due to aforementioned reason. Additionally, it was observed that very common species are found in USM Housing indicating that the area is disturbed. This could be possibly attributed to domestic run offs making the habitat of odonates polluted. This is also supported by the dominance of Pantala flavescens which could thrive in places inhabited by people and as well as this species feeds on insects such as mosquitoes which thrives in stagnant water. 
Table 2. Diversity Indices of Odonata in USM, Kabacan, Cotabato 2014

\begin{tabular}{lrr}
\hline \hline Indices & Housing & USMARC \\
\hline Shannon H' & 0.534 & 0.792 \\
Abundance & 0.778 & 0.954 \\
Evenness & 0.686 & 0.83 \\
\hline \hline
\end{tabular}

Parker-Berger index measurement of disturbance on biodiversity showed that both areas are disturbed- Housing 63\% and USMARC 37\%. Result shows that the sampling sites are somewhat disturbed due to environmental and anthropogenic factors. One reason might be due to the usage of herbicide and insectides in the two sampling areas. According to Soniyagandhi and Kumar (2014) that a higher reduction of odonatan in the treatment with herbicide + insecticide. Arulprakash and Gunathilagaraj (2011) reported high susceptibility of odonata to pesticides and repeated application might result in a reduction of most species. Villanueva and Mohagan (2010) stated that high disturbance level for odonatan in agro-ecosystem is due to their close association with water habitat. Furthermore, Oppel (2006) reported that habitat disturbance even for small-scale subsistence farming has tremendous impact on odonata diversity.

The similarity of species composition using Bray-Curtis showed that $7 \%$ of the species are common to both habitats, and $92 \%$ are discorcodant species which means that each habitat is unique for odonata (Figure 2). Both are agricultural areas, but housing differs in such domestic activities which are being introduced.

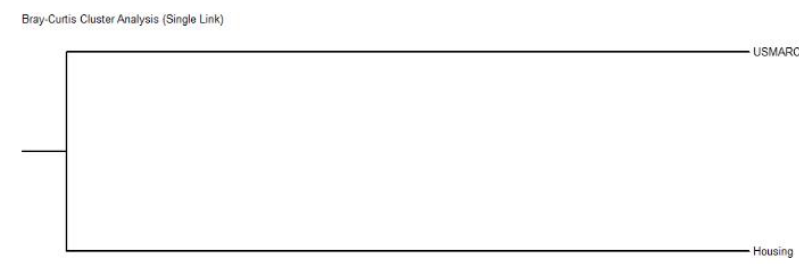




\section{CONCLUSIONS AND RECOMMENDATIONS}

The University of Southern Mindanao has low species diversity and low endemism of odonata which is an indicator that the area is already disturbed as measured by the high number of common/oriental species as well as the existence of environmental and anthropogenic activities. It is recommended that prolong sampling will be done to document more species that might be useful in any conservation effort to be imposed in the said area with regards to odonata population.

\section{ACKNOWLEDGEMENT}

We are thankful to Dr. James Gregory C. Salem and Marvin for helping during the conduct of the study as well as to Dr. Francisco Gil Garcia-USM President for allowing the investigators to conduct this study.

\section{LITERATURE CITED}

Anbalagan V, Paulraj MG, Ignacimuthu S. 2013. Odonata diversity (Insecta: Arthropoda) in rice and vegetable fields in a north-eastern district of Tamil Nadu, India. Journal of Research in Biology 3(4):977-983.

Adarsh CK, Aneesh KS. Nameer PO. 2014. A Preliminary Checklist of Odonates in Kerala Agricultural University (KAU) Campus, Thrissur District, Kerala, Southern India. Journal of Threatened Taxa 6(8):6127-6137.

Amoroso VB. 2007. Long-term biodiversity research programme for Mindanao, Philippines. Central Mindanao University, Musuan, Bukidnon, Philippines. Retrieved March 11,2014 from www.klter.org/EVENTS/Conference99/ doc/Victor.htm.

Arulprakash R, Gunathilagaraj K. 2011. Impact of agrochemicals on the abundance and diversity of odonata in rice fields. Indian Journal of Plant Protection 39 (3):191-195

Bora A, Meitei LR. 2014. Agricultural Research (ICAR), Research Complex for NEH Region Campus, Umiam, Meghalaya, India. Journal of Entomology and Zoology Studies 2(6):16-21 
Cayasan RD, Limitares DE, Gomid JVS, Nuneza OM, Villanueva RJT. 2013. Species richness of Odonata in selected freshwater systems in Zamboanga del Sur, Philippines. AACL Bioflux 6(4):378-390.

Dalzochio MS, Costa JM, Uchoa MA. 2011. Diversity of Odonata (Insecta) in lotic systems from Serra da Bodoquena, Mato Grosso do Sul State, Brazil. Revista Brasileira de Entomologia 55:88-94.

Dorji T. 2014. New Records of dragonflies (Odonata) from Toebirongchhu sub-watershed in Punakha District, Western Bhutan. Journal of Entomology and Zoology Studies 2(4):51-57.

Jomoc DJG, Flores RRC, Nuneza OM, Villanueva RJT. 2013. Species Richness of odonata in selected wetland areas of Cagayan de Oro and Bukidnon, Philippines. AACL Bioflux 6(6):560-570.

Kandinabe M, Raguraman S, Ganapathy N. 2005. Relative abundance and diversity of Odonata in an irrigated rice field of Madurai, Tamilnadu. Zoo's Print J., 20(11):2051-2052

Mapi-ot EF, Taotao AU, Nuneza OM, Villanueva RJT. 2011. Species diversity of adult Odonata in selected areas in Misamis Occidental Province, Philippines. AACL Bioflux 6(4):421-432.

Malawani AD, Ampang-Macabuat NM, Nuneza OM, Villanueva RJT. 2014. Odonata of Lanao del Sur, Mindanao, Philippines. International Research Journal of Biological Sciences 3(1):42-48.

Nelson B, Ronayne C, Thompson R. 2011. Ireleand Red List No.6: Damselflies \& Dragonflies (Odonata). National Parks and Wildlife Service, Department of the Environment, Heritage and Local Government, Dublin, Ireland. pp. 4.

Oppel S. 2006. Comparison of two odonatan communities from a natural and modified rainforest in Papua New Guinea. IJO 9(1):89-102.

Quisil JC, Nuneza OM, Villanueva RJT. 2014. Impact of mine tailings on the species diversity of Odonata fauna in Surigao Del Sur, Philippines. Journal of Biodiversity and Environmental Sciences 5(1):465-476. 
Remsburg AJ, Olson AC, Samways MJ. 2008. Shade alone reduces adult dragonfly (Odonata:Libellulidae) abundance. J Insect Behav 21:460-468

Saha PD, Gaikwad SM. 2014. Diversity and abundance of Odonata in parks and gardens of Pune City. Journal of Entomology and Zoology Studies 2(5):308-316.

Soniyagandhi M, Kumar K. 2014. Impact of agrochemicals on odonatan in rice (Oryza sativa L) ecosystem. JBiopest 7(1):52-56.

Tiple AD. 2012. Butterfly species diversity, relative abundance and status in Tropical Forest Research Institute, Jabalpur, Madhya Pradesh, Central India. Journal of Threatened Taxa 4(7):2713-2717.

Tiple AD, Paunikar S, Talmale SS. 2012. Dragonflies and Damselflies (Odonata:Insecta) of Tropical Forest Research Institute, Jabalpur, Madhya Pradesh, Central India. JoTT 4(4):2529-2533.

Thomas CD, Cameron A, Green RA, Bakkenes M, Beaumont LJ, Collingham YC, Erasmus BFN, de Siqueira MF, Grainger A, Hannah L, Hughes L, Huntley B, van Jaarsveld AS, Midgley GF, Miles L, Ortiga-Huerta MA, Peterson AT, Phillips OL, Williams SE. 2004. Extincgtion risk from climate change. Nature 427:145-148.

Villanueva RJT, Mohagan AB. 2010. Diversity and Status of Odonata across vegetation types in Mt. Hamiguitan Wildlife Sanctuary, Davao Oriental. Asian Journal of Biodiversity 1(1):25-35.

Villanueva RJ. 2011a. Odonata of Siargao and Bucas Grande Islands, The Philippines. International Dragonfly Fund-Report 34:1-25.

Villanueva RJ. 2011b. Odonata Fauna of Diomabok Lake and its surroundings, Davao Oriental, Mindanao Island, Philippines. International Dragonfly Fund-Report.38:1-29.

Villanueva RJT. 2012. Odonata recorded in February 2012 in Isabela and Aurora Provinces, Luzon Island and Polilo Island, Philippines. International Dragonfly Fund-Report 49:1-42

Williams DD, Feltmate B. 1992. quatic Insects. CAB International, Wallingford, UK 


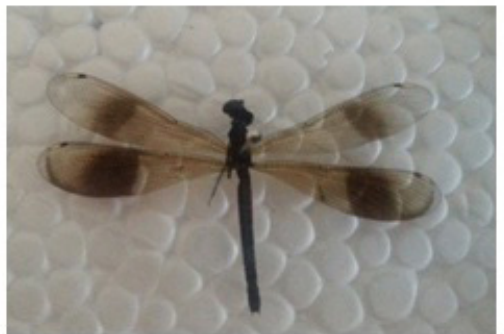

Rhinocypha colorata Selys

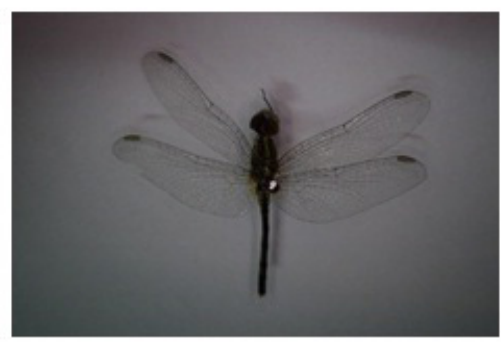

Diplacodes triviales Rambur

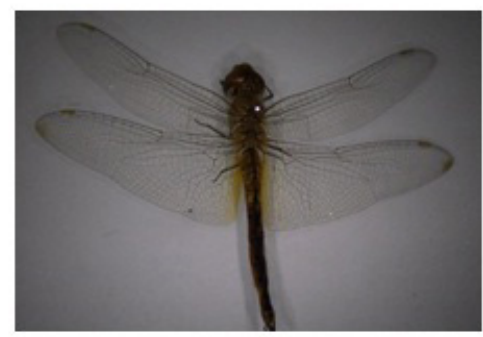

Pantala flavescens Fabricius

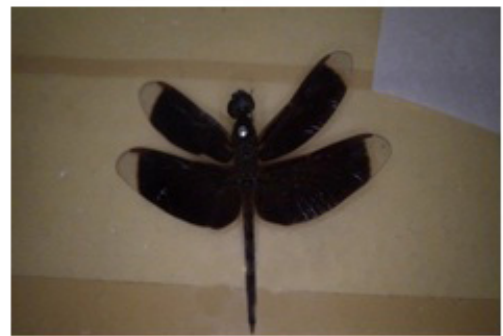

Neurothemis terminate Ris

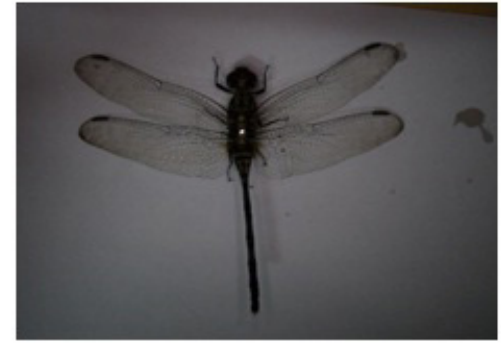

Orthetrum sabina sabina Drury

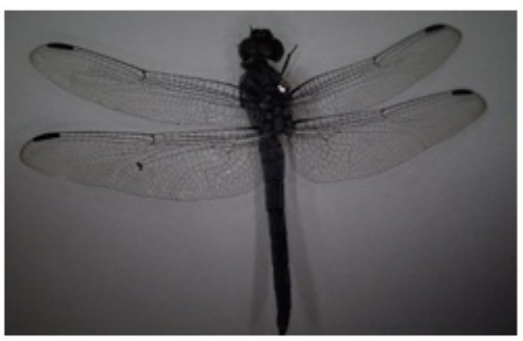

Potomarcha congener Rambur

Plate 3. Identified Odonata in University of Southern Mindanao 